\title{
An Application of Financial Ratio Analysis on Concordat Firms: A Model Suggestion on Construction
} Firms Listed in Borsa Istanbul

\author{
Mustafa ÖZYEȘiL \\ Istanbul Aydın University, Business Management, Istanbul, Turkey \\ mozyesil@aydin.edu.tr
}

\begin{abstract}
The main purpose of this study is to apply a detailed financial ratio analysis on the firms that have declared concordat, to determine which kind of financial ratios predict the more successful preliminary estimations and to form a model according to the findings obtained and to apply this model to the firms operating in Borsa Istanbul construction sector. For this purpose, the last 5 years' financial statements of the two companies whose shares are traded on Borsa Istanbul and declared concordat are analyzed by the ratio analysis method. As a result of the analysis, it was found out that the ratios that gave the strongest concordat signal are the liquidity and financial structure ratios. According to the results of the analysis, a model that can be used for the general of the companies is proposed by giving weight to each rate type. In order to test these findings, the model is applied to the financial statements of three companies operating in Borsa Istanbul construction sector and financial ratio scores of firms are calculated over the years. According to the results of the analysis, it is found that the financial situation of the construction firms is much better than the ones of the firms that has declared concordat. However, when the construction firms are compared with each other, it can be stated that YYAPI is lagging behind others in terms of financial performance.
\end{abstract}

Keywords: Financial Analysis, Ratio Analysis, Concordat, Model Construction.

\section{Introduction}

The financial statements issued by the firms have vital importance for the information users during the decision-making process. It is available to classify information users as internal ones that include shareholders, managers, and employees and as external ones that include suppliers, customers, investors, financial institutions, government and so on. As stated in article 3 of the international auditing standards (IAS), the financial statements of the firms represent financial claims for the mentioned users, particularly for external ones. Therefore, these claims must be confirmed and analyzed analytically. Verification of financial assets is carried out by an independent audit process and includes checking whether each financial statement item exists and shows the correct amount. Analytical analysis, on the other hand, is defined as a part of the independent audit process, but actually refers to the concept of financial analysis. Financial analysis is the process of analyzing the audited financial statements of the firm in an analytical manner and generating the necessary signals to the management about the financial and operational performance of the firm. Financial analysis is the process of analytically examining the financial and operational results of firms.

Financial analysis is the process of examining and interpreting financial statements using generally accepted analysis techniques (Gümüş et al., 2017). Financial analysis is performed to measure financial performance. Financial performance analysis includes the calculation of activity and financial performance indicators, determination of financial position of firms and measurement of the efficiency and risks of investments made based on historical financial statement information of a company and form the basis for the financial projection to be made for the next years (Gümüș et al., 2017).

Proper financial analysis sheds light on decision-makers on the following issues (Çelik, 2017):

- Operational performance

- Realization rate of targets

- Equity adequacy / Leverage level

- Important information and feedback on costing and pricing is provided.

The benefits of financial analysis and the information users they serve are summarized in the table 1 below: 
Table 1: Benefits of Financial Analysis and the Information Users they serve

\begin{tabular}{|c|c|}
\hline Indicator & Explanation \\
\hline Operational performance & $\begin{array}{l}\text { It provides crucial information } \\
\text { about the company's business } \\
\text { model. } \\
\text { Receivables turnover rate and } \\
\text { inventory turnover rate are the } \\
\text { main indicators of how effective } \\
\text { and risky a business model that } \\
\text { firms have. }\end{array}$ \\
\hline Realization rate of targets & $\begin{array}{l}\text { It is examined whether the } \\
\text { managers of the company have } \\
\text { achieved the financial and } \\
\text { operational success indicators } \\
\text { determined in the budget of each } \\
\text { year. }\end{array}$ \\
\hline
\end{tabular}

Equity adequacy / Leverage level It provides critical information about the financial risk level of the firms.

Financial fragility will increase as the leverage level of firm increases.

Information User / Related Party

Covers both Internal (Managing Partners) and External (Investors, Financial Institutions, Government) Information Users.

Managers need this information in internal performance evaluation and decision processes.

As external information users, financial institutions and investors need this information to evaluate the risk and return of the firm's business model.

Mostly used by managers who Internal Information User.

In addition, investors may have information based on the declarations made by the company through the material disclosure statements within the scope of PR \& IR practices.

This indicator also concerns both internal and external information users.

Investors determine the level of investment by measuring the risk of the firms.

Adequate and sustainable cash flows are required to meet the financing expenses arising from the increasing debt level of the firm.

Otherwise, the company will have to cover its debt by relying on other debts and after a certain period of time, the financial collapse will be inevitable.

Costing and pricing behaviors Both pieces of information are among the strategic financial management issues of the firms.

Today, many companies are unable to calculate their unit costs precisely because they fail to constitute an effective cost accounting system.

In addition, many companies do not show the necessary sensitivity to the pricing process and generally prefer traditional pricing methods such as cost + expected profit margin.

Source: Author's Own Explanations credit allocation for the firm by doing the credibility analysis of the firm according to the indebtedness level.

Both external and internal sides need this kind of information. 
The objectives of the financial analysis are summarized below (İskenderoğlu et al., 2015):

- A comparative analysis of the annual or quarterly financial statements of the firms, to obtain indicators of the entity's asset and debt structure.

- Examining the financial statements of the companies in the previous periods to determine the progress of the firm during the analysis period.

- To measure the relative performance of the analyzed firm's financial and operational results in comparison with the results of firms of similar size and operating in the same sector in other words, comparing with the industry average.

- Calculation of historical payment performance of a company that requests a loan, deciding the repayment capacity and making a final decision on the allocation of loans.

- Preparation of the investment budget needed for the investment decisions of the firms.

The most commonly used techniques in financial analysis can be listed as follows (Karadeniz, 2016):

- Horizontal Analysis (Comparative Financial Statements Analysis)

- Vertical Analysis (Vertical Percentage Analysis)

- Trend Analysis (Trend Percentage Analysis)

- Ratio Analysis (Financial Ratio Analysis)

The ratio establishes a relationship between two different financial items. In this respect, ratio analysis calculates the financial metrics which are the pioneer for firms by dividing 2 different financial items to each other. While all other analyzes are applied separately to balance sheet and income statement, income statement and balance sheet items are used together in ratio analysis and the relationship between them is revealed. Ratio analysis is classified under 4 headings; Liquidity Ratios, Financial Structure Ratios, Activity Ratios and Profitability Ratios (İç et al., 2015). A description of each ratio and its related formula is shown in Table 2 as follows:

Table 2: Financial Ratios Breakdown

\begin{tabular}{|c|c|c|}
\hline Liquidity Ratios & Formula & Explanation \\
\hline Current Ratio & $\begin{array}{l}\text { Current Assets / Short Term } \\
\text { Liabilities }\end{array}$ & $\begin{array}{l}\text { It shows how many times the } \\
\text { business entity is able to pay its } \\
\text { short-term debts during one fiscal } \\
\text { year. } \\
\text { It indicates how many times a firm } \\
\text { can afford to pay back its short- }\end{array}$ \\
\hline Acid - Test Ratio & $\begin{array}{l}\text { (Current Assets - Inventories) / } \\
\text { Short Term Liabilities }\end{array}$ & $\begin{array}{l}\text { term debts during a fiscal year } \\
\text { after excluding inventories which } \\
\text { is one of the slowest items to be } \\
\text { converted to cash. } \\
\text { It shows how many times the }\end{array}$ \\
\hline Cash Ratio & $\begin{array}{l}\text { (Current Assets - Inventorie - } \\
\text { Trade Receivables) / Short Term } \\
\text { Liabilities }\end{array}$ & $\begin{array}{l}\text { business entity can repay its } \\
\text { short-term debts only relying on } \\
\text { the cash and cash equivalents item } \\
\text { during a fiscal year. }\end{array}$ \\
\hline Fiscal Structure Ratio & Formula & Explanation \\
\hline Leverage Ratio & Total Debt / Total assets & $\begin{array}{l}\text { entity's assets are financed by } \\
\text { debt. }\end{array}$ \\
\hline Short-Term Liabilities \% & $\begin{array}{l}\text { Short-Term Liabilities / Total } \\
\text { Assets }\end{array}$ & $\begin{array}{l}\text { debts in total assets which are } \\
\text { more risky than long-term debts } \\
\text { due to maturity. }\end{array}$ \\
\hline Profitability Ratios & Formula & Explanation \\
\hline
\end{tabular}


Gross Profit Margin \%

Operating Profit Margin \%

Ebidta \%

Return on Assets

Return on Equity

Activity Ratios

Trade Receivables Turnover Ratio

Inventory Turnover Ratio

Asset Turnover Ratios
Gross Profit / Net Sales

Net Operating Profit / Net Sales
(Profit Item Before Interest, Tax, Amortization, and Depreciation) / Net Sales

Net Profit / Total Assets

Net Income / Total Equity

\section{Formula}

Net Sales / Average Trade Receivables

Net Sales / Average Inventories

Net Sales / Average Assets
Shows the difference \% between net sales and cogs.

It shows the net added value remaining to the business entity after the deduction of operating expenses together and cogs from net sales item.

EBIDTA, which is the real cash generating indicator of the firm, is calculated by adding the expenses that do not require cash outflow to the operating profit.

EBIDTA\% represents the EBIDTA amount remaining to the firms for each 1 TL sale.

It shows how much of the firm's 1 TL asset investment remains to the firm as profit.

It shows how much of the firm's 1 TL equity investment remains to the firm as profit. This rate is used especially for calculating the payback period of the money provided by the shareholders.

\section{Explanation}

It shows how many times the firm can collect its trade receivables from its customers during a fiscal year.

It shows how many times the firm can sell its all products to the customers during a fiscal year.

It indicates how many times the firms convert their assets to sales during a fiscal year.

Source: (Kanapickienė and Grundienè, 2015)

The financial analysis is based on the firm's historical financial statements. In this way, the historical performance of the companies is measured. It also forms the basis for the preparation of financial projections based on forecasts that management will determine in the light of historical averages. In this respect, financial analysis not only performs detailed performance appraisal of previous periods but also generates important signals for future periods. The aim of this study is to create clues by calculation financial metrics through the financial analysis of firms. The main purpose of this study is to conduct financial analysis for the firms that announced concordat and by modeling the results of these firms a new model will be established that may illuminate other firms listed in Borsa Istanbul - Construction sector. In the second part of the study, the previous study about financial analysis is discussed in detail. Section 3 will provide information about sample construction and methodology. In sections 4 and 5, the test results will be shared and the results of the analysis will be interpreted. The data used in the analysis are based on the financial statements for the 20142015 and 2015-2016 harvest periods of 150 plants. In the study, they divided the sample into groups and applied discriminant and clustering analysis.

\section{Literature Review}

Rodrigues and Rodrigues (2018), tried to determine the financial situation of the sugarcane sector in Brazil and to provide the necessary information about the investors, company managers and the decisions to be 
made to the government. According to the results of the analysis, it shows that the sector presents a heterogeneous structure due to different company groups in the sector. The results of the analysis show that it is difficult to increase the production capacity in the short term, but recovery is possible in the medium and long term provided that the general market conditions are positive and the institutional framework of the country's fuel sector is permanent. Arkan (2016), showed the use of financial ratios derived from financial statements in the stock markets of developing countries in estimating stock price movements. In the Kuwait financial market during the 2005-2014 analysis periods the predictive power of 12 financial ratios was analyzed on fifteen firms from three sectors. After the ineffective variables were eliminated from the analysis by STEPWISE method, multiple regression analysis was applied to estimate the stock price for each sector. According to the results of the test, it was determined that some ratios, especially ROA, ROA and Net Profit Ratio could provide strong signals of the relationship with stock price behavior and trend for industrial firms. The most effective ratios for investment and service sectors are ROA, ROE, P / E and EPS ratios, respectively. Zorn et al. (2018) used financial ratios as sustainability measures in the agricultural sector.

In their studies, they included the most frequently used financial ratios in the analysis by taking into account the different practices between Europe and North America in farm management. While 5 of the ratios used in the analysis are related to profitability indicators, 4 of them are related to liquidity indicators. The other eight financial indicators are related to financial efficiency, financial stability and repayment capacities of firms. More than 14,000 financial data of dairy farms from the Swiss Farm Accounting Data Network (FADN) were analyzed. Spearman correlation analysis was performed for normalized and harmonized financial ratios. According to the results of the correlation analysis, a positive relationship was found between financial ratios and economic sustainability. They calculated the compound average of the 17 financial ratios used in the analysis for Europe and North America separately and obtained similar results with the general results. Banerjee et al. (2016), analyzed efficiency of the ratings of the initial public offerings in the primary market. They observed that although the rating methodology of rating agencies seemed different, they were essentially the same in terms of basic characteristics. In the sample, ratios related to profitability, liquidity and credit quality data of 5 major commercial banks of South Africa were used.

They observed that all rating agencies used financial ratios, which is one of the analytical tools to rate initial public offerings, and as a result, they measured the impact of financial ratios on the rating of initial public offerings. In the analysis, they used the liquidity and profitability ratios as an estimator in the prediction studies and tested whether the issuers' liquidity and profitability ratio performances before the initial public offering continued after the issuance. In this way, they measured whether the investors who purchased stocks from the first issue would obtain positive returns. For this purpose, a sample based on 35 graded initial public offerings between 2011 and 2013 was analyzed. In the analysis, they used 15 profitability and liquidity ratios of the firms performed initial public offerings as independent variables. In order to determine the factors affecting IPO rating, they applied factor analysis to these independent variables. They also performed a regression analysis in order to analyze the estimation power of financial ratios in IPO rating. According to the results of the analysis, they found that the interest coverage ratio could explain the IPO rating statistically significantly. Kumbirai and Webb (2010) investigated the financial performance of commercial banking industry in South Africa during the 2005-2009 periods. They found that the use of Fintech data provided more benefits to investors.

According to the results of the study, all bank performance indicators increased significantly during the first 2 years of the analysis period. According to analyze it was stated that a significant change was observed in the trend in 2007 when the global financial crisis erupted and this change peaked in 2008-2009. It was stated that this situation resulted in insufficient liquidity, low profitability and deteriorating credit quality in South Africa's banking system. Sueyoshi (2005) used financial ratio analysis to measure the financial performance of energy sector in USA. In the analysis, the firms in the sample were divided into two groups as default and non-default firms. In the final version of the sample, financial data of 147 non-default firms and 24 default firms were used. Nonparametric discriminant analysis was used in the analysis. It is underlined that such weight estimates provide an assessment score of the discriminatory function as well as a total measure of financial evaluation in which the financial performance of power / energy firms can be determined. The results of the analysis showed that both leverage ratio and return on equity ratio are he important financial 
factors that protect firms from bankruptcy or financial turbulence. The findings from the US energy sector were compared with European and Japanese firms.

He observed that Japanese energy firms are sufficient in terms of managerial and financial skills, even if the US financial analysis standards are applied. He also stated that the results of the analysis showed that Japanese energy companies outperform than US firms. Rakićević et al. (2016), propose a logic-based methodology for the use of Dupont to analyze the financial performance of firms. The audited financial statements of the company prior to concordat will be analyzed in Excel 2016. In their study, the Dupont method is described as a basic performance indicator to decompose the return on equity (ROE) into profit, turnover and leverage components and to determine the basic source of ROE. Model that they developed was applied on a sample of 18 companies operating in the automotive sector Grennan and Michaely (2019), Described market intelligence Fintech as process that gathers many data sources including nontraditional ones and uses artificial intelligence to make investment suggestions. By using data from Fintech, they evaluate the relationship between data coverage at Fintech and market efficiency. According to the results of the analysis, they found out that price information was higher for stocks with wider field coverage of Fintech and traditional sources of information had less effect on stock prices. In line with the changing behavior of investors, they found a substitution relationship between Fintech data and traditional data.

\section{Sample Construction and Methodology}

In this study, for the last 5 years prior to the application date, the financial statements of the listed firms that apply for the arrangement of bankruptcy (concordat) will be analyzed by the ratio method. Main objective of this study is to evaluate the power of financial ratios in estimating the concordat and financial deterioration. In this respect, financial statements of two firms whose shares are traded on BIST and applied for concordat during the last 2 years will be analyzed. The audited financial statements of the company prior to concordat will be analyzed in Excel 2016. According to the results of the analysis, the weighting will be made among the financial ratios according to the degree to show the most obvious distortion in the financial structure. By using these weights and financial ratios a scorecard will be created for these companies that have applied for concordat. The model, which is based on the results of this scorecard, will be applied to the listed firms operating in Borsa Istanbul Construction sector and their financial situation will be interpreted in the light of the results obtained. Descriptive information about two listed firms that form the basis for the model is provided in Table 3 as follows:

Table 3: Descriptive Information of Firms that Apply for Concordat

\begin{tabular}{llllllll}
\hline Ticker & Stock Name & Industry & $\begin{array}{l}\text { Closing } \\
\text { Price } \\
\text { (trl)* }\end{array}$ & $\begin{array}{l}\text { Market } \\
\text { Value } \\
\text { (mn trl)** }\end{array}$ & $\begin{array}{l}\text { Market } \\
\text { Value } \\
\text { (mn \$)** }\end{array}$ & $\begin{array}{l}\text { Free Float } \\
\text { Ratio (\%) }\end{array}$ & $\begin{array}{l}\text { Capital } \\
\text { (mn trl) }\end{array}$ \\
\hline EMNIS & Eminiş Packaging & Paint & 1,55 & 9,6 & 1,6 & 20,8 & 6,2 \\
FRIGO & Frigo Pak Food & Food & 13 & 78 & 13,1 & 48,2 & 6 \\
\hline
\end{tabular}

Source: www.isyatirim.com

* Indicates the Closing Price Information on 26.12.2019.

** Calculated according to the Stock Closing Price Information on 26.12.2019.

\section{Financial Analysis and Model Construction}

In this part of the study, the financial statements for the 5-year period before the concordat application date will be analyzed over selected ratios for both firms. Since the concordat application of companies is made on different dates, the concordat date will be called $t$ and the financial statements for 5 years prior to $t$, will be called $\mathrm{t}-1, \mathrm{t}-2$ and so on respectively. The financial statements to be analyzed shall be financial statements prepared annually (as of the end of the year). Table 4 below indicates the related dates on which both firms declared concordat. 
Table 4: Date of Concordat Declared by the Firms

\begin{tabular}{ll}
\hline Firms & Date \\
\hline EMNIS & 25.09 .2018 \\
FRIGO & 15.07 .2016 \\
\hline
\end{tabular}

Source: www.kap.org.tr

The ratios to be used for the analysis are obtained from Kanapickienė and Grundienè (2015) study. The ratios used in the study are shown in Table 5 as follows.

Table 5: Selected Ratios

\begin{tabular}{ll}
\hline Liquidity Ratios & Formula \\
\hline Current Ratio & Current Assets / Short Term Liabilities \\
Acid - Test Ratio & (Current Assets - Inventories) / Short Term Liabilities \\
Cash Ratio & (Current Assets - Inventorie - Trade Receivables) / Short Term \\
& Liabilities \\
Fiscal Structure Ratio & Formula \\
Leverage Ratio & Total Debt / Total Assets \\
Short-Term Liabilities \% & Short-Term Liabilities / Total Assets \\
Profitability Ratios & Formula \\
Gross Profit Margin \% & Gross Profit / Net Sales \\
Operating Profit Margin \% & Net Operating Profit / Net Sales \\
EBIDTA \% & (Profit Item before Interest, Tax, Amortization, and Depreciation) / Net \\
& Sales \\
Return on Assets & Net Profit / Total Assets \\
Return on Equity & Net Income / Total Equity \\
Activity Ratios & Formula \\
Trade Receivables Turnover Ratio & Net Sales / Average Trade Receivables \\
Inventory Turnover Ratio & Net Sales / Average Inventories \\
Asset Turnover Ratios & Net Sales / Average Assets \\
\hline Source: (Kapicken
\end{tabular}

Source: (Kanapickienè and Grundienė, 2015)

Financial ratio analyses are applied for both firms in Table 6 in Table 7 as follows:

Table 6: Financial Ratio Analysis of the FRIGO

\begin{tabular}{|c|c|c|c|c|c|}
\hline Liquidity Ratios & $t-5$ & $t-4$ & $t-3$ & t-2 & t-1 \\
\hline Current Ratio & 0,93 & 0,73 & 1,50 & 1,14 & 0,92 \\
\hline Acid-Test Ratio & 0,33 & 0,26 & 0,57 & 0,36 & 0,29 \\
\hline Cash Ratio & 0,05 & 0,01 & 0,30 & 0,07 & 0,02 \\
\hline Activity Ratios & $t-5$ & $t-4$ & $t-3$ & $t-2$ & $t-1$ \\
\hline Trade Receivables Turnover & 7,96 & 15,32 & 12,83 & 11,49 & 8,06 \\
\hline Inventory Turnover & 2,03 & 3,13 & 1,99 & 2,17 & 2,02 \\
\hline Trade Payables Turnover & 2,57 & 4,23 & 3,66 & 3,06 & 2,01 \\
\hline Asset Turnover & 0,65 & 0,81 & 0,65 & 0,78 & 0,77 \\
\hline Fiscal Structure Ratios & $t-5$ & $t-4$ & $t-3$ & $t-2$ & t-1 \\
\hline Leverage Ratio & 0,70 & 0,63 & 0,73 & 0,75 & 0,80 \\
\hline Short-term Liabilities \% & 0,47 & 0,50 & 0,33 & 0,41 & 0,53 \\
\hline
\end{tabular}




\begin{tabular}{llllll} 
Profitability Ratios & $\mathbf{t}-\mathbf{5}$ & $\mathbf{t}-\mathbf{4}$ & $\mathbf{t}-\mathbf{3}$ & $\mathbf{t}-\mathbf{2}$ & $\mathbf{t}-\mathbf{1}$ \\
& & & & & \\
Operating Profit Margin \% & $-3 \%$ & $-3 \%$ & $-12 \%$ & $-1 \%$ & $-2 \%$ \\
Return on Assets & $-8 \%$ & $-4 \%$ & $-11 \%$ & $-4 \%$ & $-9 \%$ \\
Return on Equity & $-26 \%$ & $-11 \%$ & $-39 \%$ & $-14 \%$ & $-47 \%$ \\
EBITDA \% & $1 \%$ & $3 \%$ & $-4 \%$ & $3 \%$ & $2 \%$ \\
\hline
\end{tabular}

When the liquidity ratios are analyzed, it is seen that the liquidity ratios of the firm are below the expected average for all years during the analysis period. The fact that the current ratio is less than 1 during all years indicates that the firm does not have sufficient current assets to meet its short-term debt. In other words, there is a negative working capital experience for the company for 5 years before the concordat. In this case, it can be said that the entity has either paid its debt with debt or sold fixed assets for its debts during the last 5 years before the concordat. Considering that the leverage ratio has increased gradually over the years, it can be considered that the firm has resorted to borrowing again to pay short-term debts. Acid-test ratio is calculated as less than one third of the current ratio. This can be explained by the high share of inventories in current assets. The average share of stocks in current assets during the analysis period is $65 \%$, which explains the reason for the low acid-test ratio.

When the trend of liquidity ratios is analyzed, it is seen that the liquidity situation of the firm improved relatively in the 2 nd and 3rd years before the concordat date. Some of this improvement in liquidity can be explained by increasing indebtedness and some by increasing efficiency in business activities. When the activity rates are analyzed, it can be considered that the turnover rate of the company is high and this situation can be seen as a positive signal for the company. This reveals that the collection period of the receivables of the firm is less than 52 days. In all years of the analysis period, the turnover rate of the receivables is higher than seven. The years in which the turnover rate of the company is relatively high are the 4th, 3rd and 2nd years before the concordat date, respectively. Despite the high turnover rate of the company, it is clear that the inventory turnover rate is not too high. Although the inventory turnover rate is greater than 1 , it is well below the sector average.

During the analysis period, the average inventory turnover rate is 2.3 for all years. This ratio shows that the company is able to sell all inventories 2.3 times in one year. Based on this information, it shows that the company converts its inventories for sale approximately every 159 days. The trade payables turnover rate is 3.10 on average during the analysis period. Accordingly, it can be inferred that the company has paid 3, 10 times commercial debt in 1 fiscal year. Therefore, it is seen that the company pays commercial debt approximately every 117 days. The collection period of the receivables, inventory turnover period and commercial debt payment period can be gathered and the cash conversion cycle of the company can be calculated as follows:

$$
C C C=A C P O R+A T P O I-A T P P P
$$

The explanations of the notations in the formula are as follows:

CCC $=$ Cash Conversion Cycle

ACPOR = Average Collection Period of Receivables

ATPOI $=$ Average Turnover Period of Inventories

ATPPP = Average Trade Payables Payment Period

The cash conversion cycle of the firm during the analysis period by years is shown in Table 7:

Table 7: CCC Calculations of the FRIGO by Years

\begin{tabular}{llllll}
\hline Items & $\mathbf{t}-\mathbf{5}$ & $\mathbf{t}-\mathbf{4}$ & $\mathbf{t}-\mathbf{3}$ & $\mathbf{t}-\mathbf{2}$ & $\mathbf{t}-\mathbf{1}$ \\
\hline ACPOR & 45,87 & 23,83 & 28,46 & 31,77 & 45,30 \\
ATPOI & 179,44 & 116,60 & 183,02 & 167,94 & 180,56 \\
ATPPP & 142,12 & 86,33 & 99,86 & 119,28 & 181,78 \\
CCC & $\mathbf{8 3 , 1 9}$ & $\mathbf{5 4 , 0 9}$ & $\mathbf{1 1 1 , 6 2}$ & $\mathbf{8 0 , 4 2}$ & $\mathbf{4 4 , 0 8}$ \\
\hline
\end{tabular}


As known, the cash conversion cycle is the period in which the company's cash outflows will be returned to them as cash inflows. The higher the cash conversion period, the longer the company's access to cash will be. The cash conversion cycle of the firm is calculated as positive throughout the years of the analysis period. However, the period with the highest cash conversion cycle is the third year before the concordat application. During these periods, the periods of financial payments are not taken into account. Here, the cash conversion time is calculated entirely by considering the commercial cycle. For an overall cycle, periods of financial payments must also be taken into account. In this case, the cash conversion period will also increase by including the duration of the financial payments. When the ratio analysis results of Frigo are examined, two main findings are obtained. The first finding is that financial ratios have generally been able to produce a precursor signal in the last five years prior to the concordat. Looking at all ratios in the last 5-year analysis period, they all indicate a negative process leading to concordat. When the estimation power of the ratios is examined for the last 5 years it can be concluded that financial ratios indicate the bad situation of the company and can produce the necessary early signals.

The second finding is related to the analysis of the analysis period year by year. Although it can generate accurate signals regarding the financial position of the firm in the last 5 years before the concordat, the strength of these signals is not the same for each year. In particular, it can be easily seen from the table that the company's financial turbulence has started to improve relatively as it approaches the concordat date. In other words, although negative signals continue in financial ratios, a relative improvement towards the date of concordat also is observed. Then this question should arise: Either this improvement is not sufficient to ensure that the firm may not need to declare concordat or there is financial manipulation occurred in the financial items that form the basis of the firm's financial ratios. According to the results of the analysis, it can be assumed that the financial ratios that gave the strongest concordat signal in the last 5-year period before the concordat are Liquidity and Financial Structure Ratios. Based on this finding, it can be accepted that activity rates have improved relatively over the 5 -year period. Therefore, possible financial manipulation can be found in financial items subject to activity ratios.

Table 8: Financial Ratio Analysis of the EMNIS

\begin{tabular}{|c|c|c|c|c|c|}
\hline Liquidity Ratios & t-5 & $\mathrm{t}-4$ & $\mathrm{t}-3$ & t-2 & $t-1$ \\
\hline Current Ratio & 0,38 & 0,50 & 0,39 & 0,39 & 0,54 \\
\hline Acid-Test Ratio & 0,27 & 0,40 & 0,28 & 0,30 & 0,43 \\
\hline Cash Ratio & 0,00 & 0,00 & 0,00 & 0,00 & 0,01 \\
\hline Activity Ratios & $t-5$ & $t-4$ & $t-3$ & $\mathrm{t}-2$ & $t-1$ \\
\hline Trade Receivables Turnover & 4,38 & 6,54 & 4,63 & 4,29 & 2,84 \\
\hline Inventory Turnover & 7,89 & 8,86 & 8,04 & 8,94 & 7,10 \\
\hline Trade Payables Turnover & 3,92 & 124,21 & - & - & - \\
\hline Asset Turnover & 0,86 & 0,94 & 0,85 & 0,75 & 0,91 \\
\hline Fiscal Structure Ratios & t-5 & $\mathrm{t}-4$ & $t-3$ & $t-2$ & $\mathrm{t}-1$ \\
\hline Leverage Ratio & 0,91 & 0,90 & 0,95 & 0,97 & 0,92 \\
\hline Short-term Liabilities \% & 0,50 & 0,53 & 0,62 & 0,75 & 0,81 \\
\hline Profitability Ratios & t-5 & $\mathrm{t}-4$ & t-3 & $\mathrm{t}-2$ & t-1 \\
\hline Operating Profit Margin \% & $-18 \%$ & $-6 \%$ & $-11 \%$ & $-20 \%$ & $1 \%$ \\
\hline Return on Assets & $-26 \%$ & $-15 \%$ & $-19 \%$ & $-31 \%$ & $-7 \%$ \\
\hline Return on Equity & $-282 \%$ & $-151 \%$ & $-393 \%$ & $-1096 \%$ & $-84 \%$ \\
\hline Ebitda \% & $-6 \%$ & $5 \%$ & $-5 \%$ & $-13 \%$ & $5 \%$ \\
\hline
\end{tabular}


Similar to Frigo, liquidity ratios are well below the expected value which is 1.5. Particularly, the current ratio is around 0.5 , indicating that the company can only cover half of its short-term debt even if it sells all of its current assets. When we look at the activity ratios, similar to the Frigo Company the activity rates are more favorable than the other rate types. The average trade receivable turnover rate for the last 5 years is 4.5 . This result reveals that the company made approximately 4.5 collections from customers during 1 fiscal year. According to the receivables turnover rate, the collection period of the company is calculated as 81 days. The inventory turnover ratio is calculated as approximately 8.17 for the last 5 years. Based on this information, the turnover period of inventories of the firm for sale is calculated as 44, 68 days. Since the company did not have any trade payable debts in the last 3 years before the concordat, the turnover period of commercial debt could not be calculated for these years. Based on this information, the cash conversion cycle of the firm is calculated in Table 9 as follows:

Table 9: CCC Calculations of the EMNIS by Years

\begin{tabular}{llllll}
\hline Items & $\mathbf{t}-\mathbf{5}$ & $\mathbf{t}-\mathbf{4}$ & $\mathbf{t}-\mathbf{3}$ & $\mathbf{t}-\mathbf{2}$ & $\mathbf{t}-\mathbf{1}$ \\
\hline AOTS & 83,30 & 55,81 & 78,87 & 85,17 & 128,43 \\
SODS & 46,28 & 41,19 & 45,40 & 40,82 & 51,38 \\
Tİ.BO.DS & 93,17 & 2,94 & - & - & - \\
CCC & $\mathbf{3 6 , 4 1}$ & $\mathbf{9 4 , 0 6}$ & $\mathbf{1 2 4 , 2 7}$ & $\mathbf{1 2 6 , 0 0}$ & $\mathbf{1 7 9 , 8 1}$ \\
\hline
\end{tabular}

It is observed that the cash conversion cycle of Eminiş is higher than Frigo. It is observed that the cash conversion period increases especially as it approaches the concordat date. In the financial ratio analysis of Eminiș, similar results to those of Frigo are observed. For the whole of the last 5 years before the concordat, all ratios confirm the financial trouble existence. However, there is a relative improvement in ratios as the concordat date approaches. According to the receivables turnover rate, the collection period of the company is calculated as 81 days. The ratio, which has the most evident improvement, is the activity ratios. Therefore, the most probable part of the firm's financial manipulation is the financial items used in the activity ratios. As a result of the detailed financial analysis of both companies that have declared concordat, it is seen that the financial ratios which make the strongest estimation in the process of declaring concordat are the liquidity and fiscal structure ratios. It is found that both ratio types accurately predict the concordat signal by approximately $70 \%$. However, since there is no statistically significant result from the sample data built on two firms, the findings cannot be generalized. In the light of the current findings, we can list the financial ratio types in order of importance for accurate signaling of financial turbulence in Table 10 as follows:

Table 10: Weights of the Ratio Types in Determining Financial Turbulence

\begin{tabular}{ll}
\hline Ratio Type & Weight (\%) \\
\hline Liquidity Ratios & $\% 40$ \\
Fiscal Structure Ratios & $\% 40$ \\
Activity Ratios & $\% 10$ \\
Profitability Ratios & $\% 10$ \\
\hline
\end{tabular}

The pre-concordat financial score for both firms is calculated by multiplying the importance of each type of financial ratio and the financial ratios of the firms during the 5-year period before the concordat in Table 11 and Table 12 respectively, as follows:

Table 11: Financial Ratio Scores of FRIGO before Concordat

\begin{tabular}{|c|c|c|c|c|c|}
\hline Type of Financial Ratios & $t-5$ & $t-4$ & $t-3$ & $t-2$ & t-1 \\
\hline Liquidity Ratios & 0,52 & 0,40 & 0,95 & 0,63 & 0,49 \\
\hline Activity Ratios & 1,32 & 2,35 & 1,91 & 1,75 & 1,29 \\
\hline Fiscal Structure Ratios & 0,47 & 0,45 & 0,42 & 0,46 & 0,53 \\
\hline Profitability Ratios & $-0,04$ & 0,01 & 0,07 & 0,02 & - 0,06 \\
\hline
\end{tabular}


Table 12: Financial Ratio Scores of EMNIS before Concordat

\begin{tabular}{|c|c|c|c|c|c|}
\hline Type of Financial Ratios & $t-5$ & $t-4$ & $t-3$ & $t-2$ & t-1 \\
\hline Liquidity Ratios & 0,26 & 0,36 & 0,27 & 0,28 & 0,39 \\
\hline Activity Ratios & 1,70 & 14,06 & \#SAYI/0! & \#SAYI/0! & \#SAYI/0! \\
\hline Fiscal Structure Ratios & 0,56 & 0,57 & 0,63 & 0,69 & 0,69 \\
\hline Profitability Ratios & 0,33 & 0,17 & 0,43 & 1,16 & 0,08 \\
\hline
\end{tabular}

Model Application to the Listed Firms Operating in Construction Industry: In the previous section, we conducted a detailed financial ratio analysis of the last 5 years before the concordat of the two companies that have declared concordat at Borsa Istanbul. In ratio analysis, we examined and graded each category comparatively according to predictive power. Finally, we multiplied each calculated ratio by weight and calculated the financial ratio score of the firms for each year. In this part of the study, financial ratio analysis of the construction companies whose shares are traded on Borsa Istanbul will be performed for 2013-2018 period and financial score calculation will be made for each year. Then, the calculated financial ratio scores will be compared with the scores of the companies that have declared concordat. Descriptive information of the companies operating in Borsa Istanbul construction sector is shown in Table 13 as follows.

Table 13: Descriptive Information of Listed Firms Operating in Construction Industry

\begin{tabular}{llllllll}
\hline Ticker & Stock name & $\begin{array}{l}\text { Closing } \\
\text { (trl)* }\end{array}$ & $\begin{array}{l}\text { Price } \\
\text { (mn trl)** }\end{array}$ & $\begin{array}{l}\text { Market Value } \\
\text { (mn \$)** }\end{array}$ & $\begin{array}{l}\text { Free Float } \\
\text { Ratio (\%) }\end{array}$ & $\begin{array}{l}\text { Capital } \\
\text { (mn trl) }\end{array}$ \\
\hline ENKAI & Enka İnşaat & 6,44 & 32.200 & 5410,9 & 11,8 & 5.000 \\
TKFEN & Tekfen Holding & 19,65 & 7.271 & 1221,7 & 50,8 & 370 \\
YYAPI & Yesil Yapi & 0,63 & 147 & 24,6 & 99,3 & 233 \\
\hline
\end{tabular}

Source: www.isyatirim.com

* Indicates the Closing Price Information on 30.12.2019.

** Calculated according to the Stock Closing Price Information on 30.12.2019.

The reasons for the adaptation of the model to construction companies are listed below:

- The construction sector will be among the trigger sectors of economic growth in Turkey as expressed in the Medium-Term Plan published by the government.

- The sector provides a lot of job opportunities for the unqualified workforce, thus making a vital contribution to employment.

- Since the construction sector has commercial transactions with many types of sectors, the improvement in this sector will directly affect other sub-sectors positively.

- Since most of the raw materials used in the sector are produced /obtained domestically, the net contribution of the sector to the current balance (current deficit) will be positive.

Based on the facts described above, it can be stated that the construction sector is prominent for the overall economy growth. Based on this determination, the financial ratio scores of the firms operating in the construction sector in Borsa Istanbul are calculated and compared with the ratios of the firms that announced concordat. The financial ratio scores of the construction firms for the last 5 years are calculated in Table 14 as follows.

Table 14: Financial Ratio Scores of Construction Sector by Years

\begin{tabular}{llllllllllllllll} 
Type & of & $\mathbf{2 0 1 8} / \mathbf{1 2}$ & \multicolumn{4}{c}{$\mathbf{2 0 1 7} / \mathbf{1 2}$} & \multicolumn{4}{c}{$\mathbf{2 0 1 6 / 1 2}$} & \multicolumn{3}{c}{$\mathbf{2 0 1 5 / 1 2}$} & \multicolumn{3}{c}{$\mathbf{2 0 1 4 / 1 2}$} \\
Financial & EN & TK & YY & EN & TK & YY & EN & TK & YY & EN & TK & YY & EN & TK & YY \\
Ratios/ & KA & FE & AP & KA & FE & AP & KA & FE & AP & KA & FE & AP & KA & FE & AP \\
Firms & I & N & I & I & N & I & I & N & I & I & N & I & I & N & I \\
\hline Liquidity & 2,3 & 1,2 & 1,0 & 1,9 & 1,1 & 0,9 & 2,6 & 0,9 & 1,1 & 2,5 & 1,0 & 0,4 & 2,2 & 1,2 & 0,5 \\
Ratios & 5 & 5 & 1 & 9 & 5 & 0 & 6 & 8 & 4 & 6 & 5 & 2 & 6 & 0 & 6 \\
Activity & 1,9 & 2,1 & 0,9 & 8,7 & 1,5 & 0,7 & 12, & 1,2 & 1,7 & 51, & 1,1 & 1,0 & 54, & 1,6 & 1,2 \\
\hline
\end{tabular}




\begin{tabular}{llllllllllllllll}
\hline Ratios & 7 & 2 & 0 & 6 & 2 & 9 & 57 & 4 & 5 & 08 & 9 & 6 & 75 & 9 & 6 \\
Fiscal & 0,1 & 0,4 & 0,2 & 0,1 & 0,5 & 0,3 & 0,1 & 0,4 & 0,1 & 0,1 & 0,4 & 0,5 & 0,2 & 0,4 & 0,5 \\
$\begin{array}{l}\text { Structure } \\
\text { Ratios }\end{array}$ & 3 & 8 & 9 & 3 & 1 & 3 & 4 & 9 & 7 & 6 & 6 & 0 & 0 & 2 & 6 \\
Profitability & 0,0 & 0,0 & 0,0 & 0,0 & 0,0 & 0,0 & 0,0 & 0,0 & 0,1 & 0,0 & 0,0 & 0,0 & 0,0 & 0,0 & - \\
Ratios & 6 & 7 & 4 & 7 & 6 & 1 & 6 & 4 & 2 & 5 & 3 & 8 & 5 & 2 & 0,0 \\
\hline
\end{tabular}

According to Table 14, it can be inferred that the financial ratio scores of the firms operating in the Borsa Istanbul construction sector are in a better financial position than the firms that have declared concordat. Therefore, it can be stated that the firms included in the analysis do not / will not have to declare concordat.

\section{Conclusion and Recommendations}

In this study, detailed financial ratio analysis is made based on the financial data of two firms that have declared concordat. The main purpose of the ratio analysis is to test the concordato estimation power of financial ratios. According to the findings, the financial ratios that give the most reliable signal that the firm has deteriorated financially are liquidity and financial structure ratios respectively. Since the sample consisted of only two firms, the results cannot be statistically generalized. We built a model based on our findings related to two firms to estimate concordat probability of the firms by using financial metrics. We applied it to construction firms listed in Borsa Istanbul. Based on financial ratio scores calculated based on our established model, it seems that firms operating in construction industry are more stable in terms of financial position. Therefore, they can be considered far from making concordat announcement. When comparison analysis is made among them, it can be said that YYAPI is underperforming compared to other firms.

Research Implications: The limitations of the study can be summarized as follows:

- Due to the small sample size, the results need statistical confirmation. Only two firms are included in the sample and the model is established based on findings of these firms. Therefore, our findings do not provide statistically reliable results.

- The construction companies to which the model is applied consist of only three major construction companies whose shares are traded on the stock exchange. Therefore, the results of the model applied to these firms do not produce statistically significant results.

- The sample which the model is based on includes different industries such as paint and food while the firms are used for the application of the model is operating in the construction industry. They significantly differ from each other and lead financial analysts to interpret each ratio differently according to the selected industry.

Proposed Furthers Research: It is strongly recommended to carry out studies that will allow comparison between countries and sectors related to financial analysis. In this way, more realistic findings can be obtained by interpreting each financial ratio according to the sector in which the company operates.

\section{References}

Arkan, T. (2016). The Importance of Financial Ratios in Predicting Stock Price Trends: A Case Study in Emerging Markets, Finanse, Rynki Finansowe, Ubezpieczenia, 79, 13-26.

Banerjee, Sanbad., Guha, Banhi. \& Bandyopadhyay, Gautam. (2016). A Post Factor Analysis of Financial Ratios of Selected IPOs and its Impact on Grading: An Empirical Inquest, Journal of Business Studies Quarterly, 8(1), 23-34.

Çelik, T. (2017). Sigorta Şirketlerinde Finansal Analiz Ve Bir Uygulama, Y.Lisans Tezi, Marmara Üniversitesi, SBE.

Gümüş, U. T. \& BOLEL, N. (2017). Rasyo Analizleri İle Finansal Performansın Ölçülmesi: Borsa İstanbul'da Faaliyet Gösteren Havayolu Şirketleri'nde Bir Uygulama, Adnan Menderes Üniversitesi, Sosyal Bilimler Enstitüsü Dergisi, 4(2), 87-96. 
Gümüş, U. T., Şakar, Z., Akkın, G. \& Şahin, M. (2017). Finansal Analizde Kullanılan Oranlar ve Firma Değer İlişkisi: Bist'de İşlem Gören Çimento Firmaları Üzerine Bir Analiz, Karadeniz Sosyal Bilimler Dergisi, $9(16), 1-23$.

Grennan, J. \& Michaely, R. (2019). FinTechs and the Market for Financial Analysis, Swiss Finance Institute Research Paper Series, 19-10.

İç, Y. T., Tekin, M., Pamukoğlu, F. Z. \& Yıldırım, S. E. (2015). Kurumsal Firmalar İçin Bir Finansal Performans Karşılaştırma Modelinin Geliştirilmesi, Journal of the Faculty of Engineering and Architecture of Gazi University, 30(1), 71-85.

İskenderoğlu, Ö., Karadeniz, E. \& Ayyıldız, N. (2015). Enerji Sektörünün Finansal Analizi: Türkiye ve Avrupa Enerji Sektörü Karşılaştırması, İşletme ve Íktisat Çalışmaları Dergisi, 3(3), 86-97.

Kanapickienè, R. \& Grundienè, Z. (2015). The Model of Fraud Detection in Financial Statements by Means of Financial Ratios, Procedia - Social and Behavioral Sciences, 213, 321-327.

Karadeniz, E. (2016). Hastane Hizmetleri Alt Sektörünün Finansal Performansının İncelenmesi: Türkiye Cumhuriyeti Merkez Bankası Sektör Bilançolarında Bir Uygulama, Hacettepe Sağlık İdaresi Dergisi, 101-114.

Kumbirai, M. \& Webb, R. (2010). A financial Ratio Analysis of Commercial Bank Performance in South Africa, African Review of Economics and Finance, 2(1), 30-53.

Rakićević, A., Milošević, P., Petrović, B. \& Radojević, D. G. (2016). DuPont Financial Ratio Analysis Using Logical Aggregation, Soft Computing Applications, 727-739.

Rodrigues, L. \& Rodrigues, L. (2018). Economic-financial performance of the Brazilian sugarcane energy industry: An empirical evaluation using financial ratio, cluster and discriminant analysis, Biomass and Bioenergy, 108, 289-296.

SUEYOSHI, T. (2005). Financial Ratıo Analysis of The Electric Power Industry, Asia-Pacific Journal of Operational Research, 22(03), 349-376.

Zorn, A., Esteves, M., Baur, I. \& Lips, M. (2018). Financial Ratios as Indicators of Economic Sustainability: $A$ Quantitative Analysis for Swiss Dairy Farms, Sustainability, 10(8), 1-20. 